\title{
New Directions in Australian Air Transport
}

\author{
Henry Ergas and Christopher Findlay
}

$\mathrm{T}$ he events of September 112001 and the Ansett collapse a few days later have had a major impact on the Australian air transport markets. In this paper, we examine the immediate and longer-term competitive outcomes associated with these developments, and review the policy issues that arise.

We focus on the markets in which air services are provided domestically within Australia ('domestic market') and on any significant detrimental effects of recent events on the process of competition in the domestic market that may provide justification for increased regulation. This may take several forms, including imposition of airline specific regulation, and/or adjustments to general legislation guarding against anti-competitive activity - for instance, section 46 of the Trade Practices Act, which relates to the taking advantage of substantial market power.

We also comment on the lack of desirability of industry-specific regulation. Our view of the case for adjustment to section 46 differs from that of the Australian Competition and Consumer Commission (ACCC). Developments in airport pricing and slot allocation, while also important, are beyond the scope of this paper. For a review of recent developments see Fels (2001) and for a discussion of policy options see Productivity Commission (2001a) as well as some discussion within Productivity Commission (1998).

\section{Events of September 2001}

Two key events in September 2001 were the attack of September 11 and the collapse of Ansett on September 14. The worldwide impact of the events of September 11 was substantial. On the demand side, there was an immediate slump in bookings (Amadeus 2001). On the supply side, while September 11 may have contributed to the high profile financial problems of several airlines, including Sabena and SwissAir, in all likelihood it merely pushed these airlines 'over the edge', as opposed to being the major cause of their problems.

It is clear that Australian demand for international air services dipped in the immediate weeks following September 11. This is evident in the most recent publicly available AVSTATS data from the Department of Transport and Regional Services (DOTRS) website, which show a year-on-year decline of traffic between September 2000 and September 2001 of 1.2 per cent (Figure 1). Traffic

Henry Ergas is Managing Director of Network Economics Consulting Group, and Christopher Findlay is Professor of Economics, Asia Pacific School of Economics and Management, The Australian National University. 
then broke from its pattern of the year before and continued to fall in October and November 2001. But it resumed its normal seasonal pattern in December, and in the first quarter of 2002 came closer to traffic levels of a year earlier.

Data reported by Qantas suggest that the immediate impact of September 11 was a downturn in demand for international air services. Qantas revealed that September 11 had affected traffic not only to the United States, but also to Europe and Asia (Qantas 2001a): however, it believed that recovery of the international air services market was 'inevitable'. In summary, it is likely that, while the events of September 11 may have had a substantial short term impact on air service markets worldwide, it is not apparent that it will have a longer lasting impact on the demand for and supply of air services.

\section{Figure 1: Total International Passengers by Month}

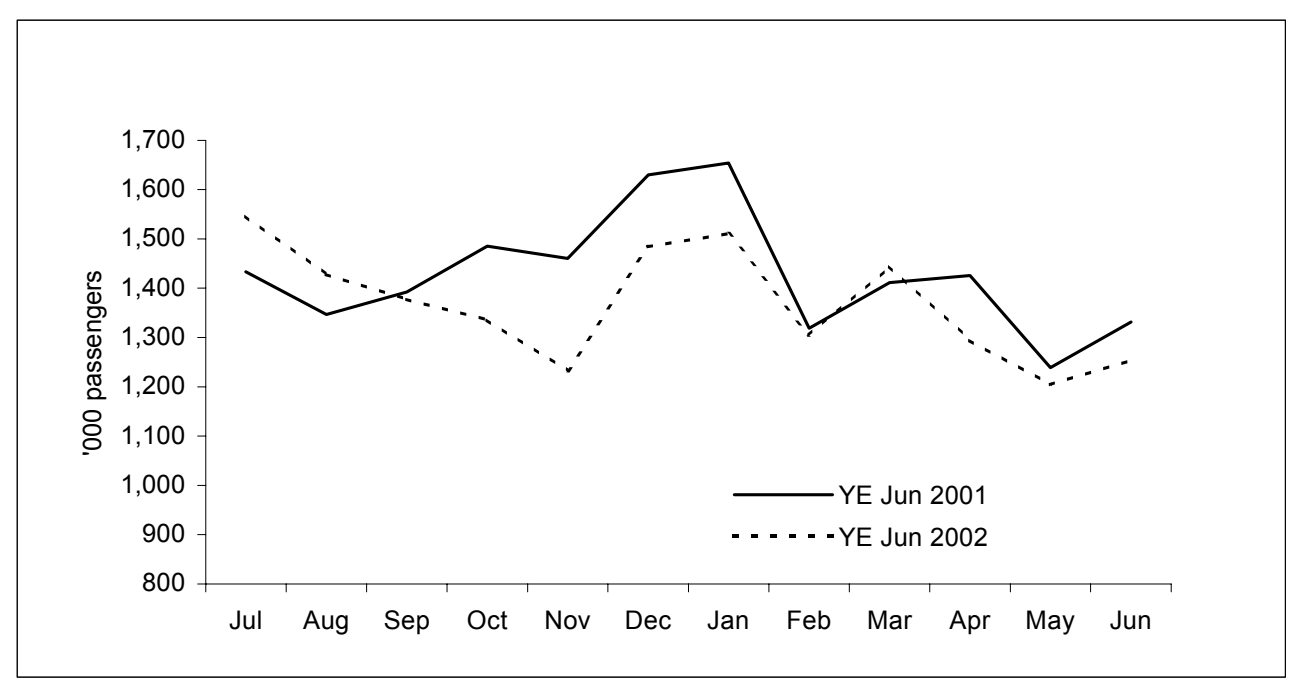

Source : http://www.dotrs.gov.au/btre/avstats/intpage

The collapse of Ansett has had longer term effects. Its withdrawal reduced the number of competing airlines along major domestic trunk routes from three to two: Qantas, a full service airline (FSA), and Virgin Blue, a value-based airline (VBA). Following the collapse of Ansett, both Qantas and Virgin added capacity to absorb excess demand. However, it is apparent that Qantas captured most of this excess, reflecting its greater ability to expand capacity in the short term (albeit at relatively high cost) and its de facto role as 'carrier of last resort'. Qantas's traffic data show the rise in volume after September 2001 following the Ansett closure (Figure 2). They also show the steady decline in traffic in 2001, which continued to November but appear to resume a normal pattern by February and March 2002. 
Figure 2: Qantas Traffic Data
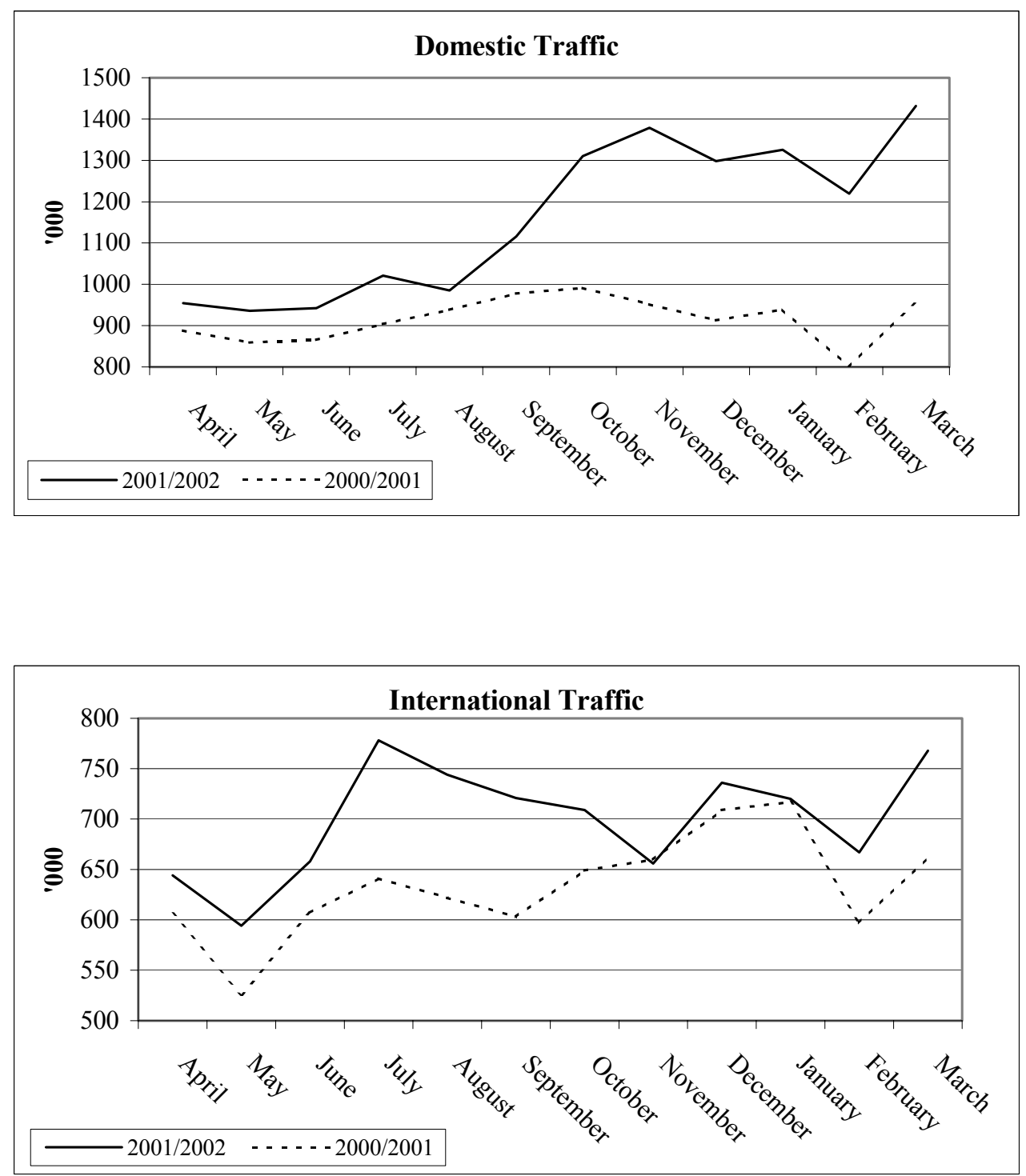

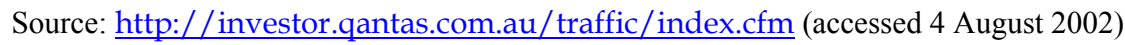




\section{Likely Effects on Competition in the Domestic Market}

Even in the period immediately prior to the collapse of Ansett, Qantas most likely had a position of some strength in the domestic market. This strength was associated with its greater efficiency relative to Ansett (though not necessarily relative to Virgin Blue). The collapse of Ansett - a competitor with a strong brand reputation, though with relatively high costs - may have increased the strength of Qantas's position. Qantas's increase in capacity may have also enabled it to derive cost reductions because of the benefits of operating a larger and denser network.

The question is then whether new entry can be expected. There are substantial barriers to entry into these markets, though the precise height of these barriers is open to debate. Examples include the sunk costs associated with establishing a brand and a reputation for reliability — not only in terms of safety but also scheduling and on-time performance. Entrants will also have to establish a network that is sufficiently large and has the right architecture to generate the same economies of density that favour incumbents, although any cost asymmetries between entrants and incumbents arising from the network and density economies are likely to be particularly relevant for potential FSAs and less of an issue for VBAs. Facilities will have to be established at each point in these networks, and little of that investment is likely to be recoverable on exit.

Another sunk cost that entrants will have to incur is that of matching the price response of incumbents. Pricing is very flexible in air transport markets, with the use of complex price structures that discriminate between passengers so as to maximise revenue on each flight (referred to as 'yield management') and internet marketing, allowing incumbents to respond rapidly to initiatives by entrants.

Responses by incumbents are not restricted to pricing, however. There are many other competitive strategies that incumbents can adopt, and in responding to these strategies entrants may incur sunk costs, the prospect of which impedes entry. These strategies include: operating (or increasing) capacity on a route or routes at fares that do not cover the avoidable cost of providing the service, or using a low-cost second-brand carrier in a similar manner; pre-empting airport facilities or services that are required by another air carrier for the operation of its business, with the object of withholding airport facilities or services from a market; using commissions, incentives or other inducements to sell or purchase seats on its flights; using a loyalty marketing program; or altering schedules, networks, or infrastructure for the purpose of disciplining or eliminating a competitor, or impeding or preventing a competitor's entry into, or expansion in, a market.

This list of possible origins of barriers to entry is impressive. There is, however, compelling US and European evidence that value-based airlines, such as Virgin Blue, have been able to surmount these entry barriers to become an especially effective source of competitive discipline. As a result, it may well be that competition between Virgin Blue and Qantas will be far more vigorous than it 
was with the former duopoly. We discuss the scope for additional competition from value-based airlines below.

There might also be scope for competition from international carriers serving Australia, and in a later section we review the regulatory impediments to entry in various forms by those airlines.

\section{Long-term viability of full service provider}

In considering likely future outcomes in the domestic market, an important consideration is the ability of Virgin Blue to competitively constrain a carrier such as Qantas. Such a consideration is related to the current debate surrounding the extent to which value-based airlines constrain full service providers, and the long term viability of the full service provider model.

There has been considerable growth in value-based airlines over recent years. Virgin Blue is one such example. Air New Zealand has recently converted to a form of value-based airline for domestic services. International success stories include easyJet and RyanAir in Europe and Southwest Airlines in the United States. RyanAir, in particular, has taken the low fare/high volume business model to new extremes. It claims that within three months of its website launch, it was taking over 50,000 bookings per week. It did this by offering airfares from as low as $£ 1$ and $£ 9$ return (plus taxes) on the Glasgow-London and Dublin-London routes, respectively. Following the events of September 11, RyanAir introduced a range of international fares for £15 (USA Today, 2001). Currently, RyanAir has a host of cheap international fares, including a Frankfurt-Bologna fare for £9.99.

Whether such value-based airlines spell the end of the full service operator as we know it depends on the extent to which, for full service providers, competing at the low fare end of the market results in cannibalisation of high yield customers. Perhaps this concern has constrained the response by the full service operators, since there is evidence to suggest that they have been unable to contain effectively-managed value-based airlines. An example is the United Kingdom. Since moving to the Southwest value-based airline model at the start of the 1990s, RyanAir has become the second largest carrier in that country.

British Airways (BA) has been indecisive in responding to value-based airlines. It had operated its own value-based airline, Go, but sold this in mid2001. BA's Chief Executive said at the time of the sale that Go did not fit with BA's full service strategy (BA, 2001). However, in a recent turnaround, it has chosen to compete head to head with its low fare rivals RyanAir, easyJet and its formerly owned Go, as noted in an April 2002 press release (BA, 2002a):

British Airways today launched a change to its fare structure on key routes within the UK to give business travellers and holiday makers lower fares, greater flexibility and more choice ...

The fare structure will be less complicated, with simple trade up steps based on choice of flight, flexibility and availability, enabling customers to trade off their needs versus price. 
This is the airline's first competitive response to the no frills carriers following last month's announcement of a major package of measures designed to return the airline to profitability.

The strategy is part of BA's 'Future Size and Shape' rationalisation and cost cutting strategy (BA, 2002b). However, in announcing the intention to compete directly with its low cost rivals, the CEO stated that BA had no intention of becoming a value-based airline or launching its own no frills airline (BA, 2002b). Instead, BA intended to use its competitive advantages, such as its extensive network, flight frequencies, convenient airports, and customer service, and to combine these with the key elements associated with successful value-based airlines, such as online bookings, high aircraft utilisation, and pricing simplicity. Investments would continue to be made to maintain the numbers of premium and frequent customers.

What has been the impact of the entry of Virgin Blue into the Australian market? A full assessment requires more data and more experience than is currently available. However a review of recent changes in fares provides evidence of impacts worthy of further attention. Figure 3: Fares and Passenger Numbers in the Australian Domestic
Market

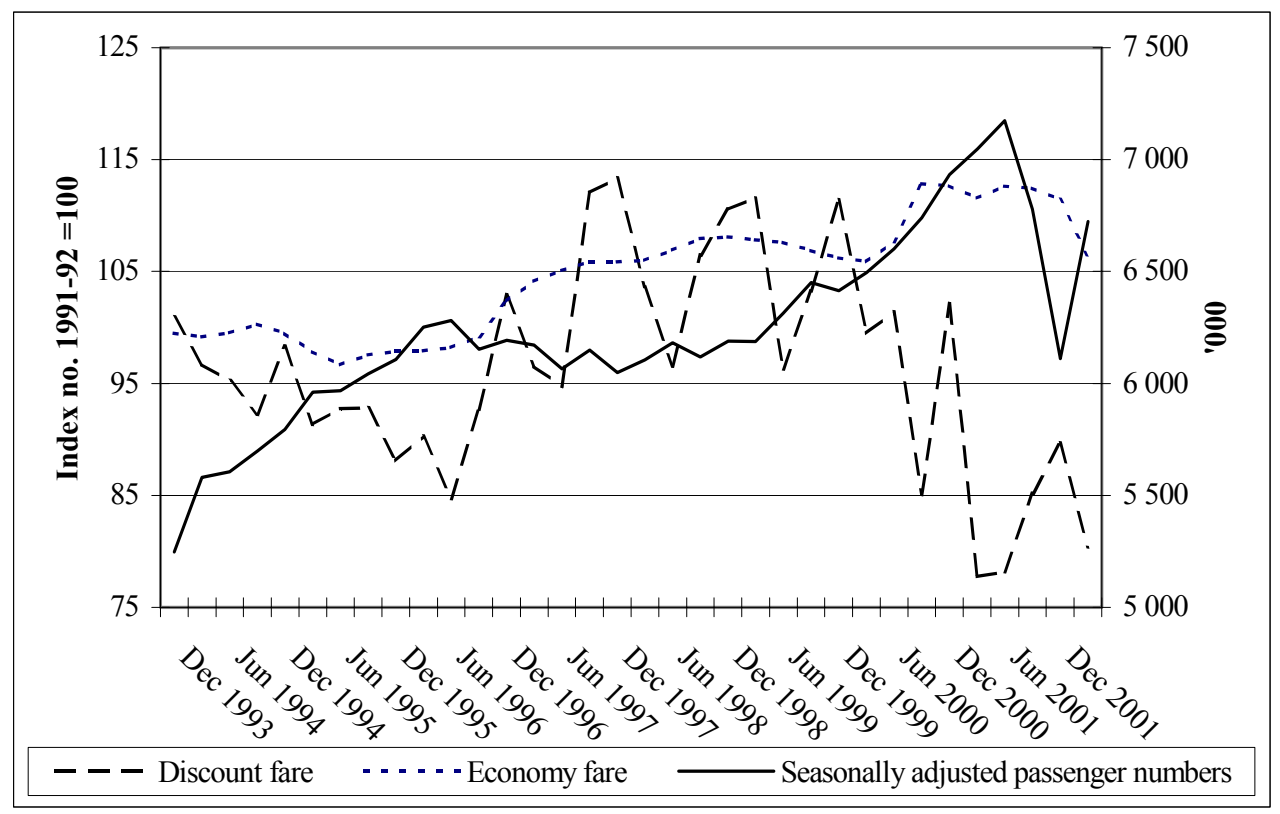

Source: http://www.dotars.gov.au/btre/indic_home.htm 
Figure 3 shows the changes in index values of economy and discount fares (left axis) and passenger numbers (seasonally adjusted, right axis). A complex set of factors explain the combinations of prices and quantities in the figure, but the features of interest are:

- the rapid growth in traffic in the first half of the 1990s, during which period economy fares were roughly constant in real terms, while discount fares were falling;

- a shift to a new level in the average economy fare from December 1996 onwards, as well as a significant shift in the relationship between discount and economy fares at the same time as traffic growth stalled; and

- from 1999, a sustained acceleration of traffic growth was followed a little later by Virgin's entry in August 2000, and then by a sharp decline in discount fares while the average economy fare moved to an even higher level.

The value-based operator, it appears, drives a wider wedge between the economy and discount fares and, as a result of the discounting its entry induces, is associated with substantial growth in traffic. The nature and significance of these effects are interesting topics for further quantitative work. That work would also need to allow for the effect of the downturn in traffic in the last quarter of 2001 associated with the events of September that year. Isolating the impact of Ansett's demise on pricing in the domestic market is also difficult because of the impact of the other events.

Like British Airways, Qantas's response to the situation from August 2000 onwards appears to be to keep all the competitive options open. For instance, while it has announced its intention to operate a low fare airline in the form of Australian Airlines, the fact that Australian Airlines is only beginning with flights from Cairns to various Asian cities suggests that Qantas is still at the stage of testing whether this strategy is workable (Qantas, 2002). Qantas says that it intends to extend services to domestic routes, but this will only occur if initial services prove not to cannibalise Qantas's high yield fares.

Value-based airlines can therefore penetrate markets of established incumbents. However their main advantage may be their greenfield nature, in which case they can operate with lower labour costs than incumbents, and they can design their networks to maximise their aircraft utilisation rates. A VBA, operating with a substantial cost advantage, is not likely to be threatened by even severe price-cutting by a high cost FSA, even if the FSA is able to reap the advantages of a sophisticated yield management system. On the other hand, if incumbents can match the costs of the entrant, then their more expansive networks and wider range of passenger types, and their consequent greater discretion in yield management systems (as long as they can also avoid the problems of cannibalisation), give them important advantages.

However it is worth noting that to date there are few signs in markets overseas of the competitive challenge VBAs pose to FSAs abating, even when VBAs have become mature, well-established operators. On the contrary, the 
persistent difficulties of the US FSAs, even in their 'fortress hubs', suggests that the challenge from VBAs will persist for many years.

There are also other sources of potential competitive pressure in the Australian market, however. One is entry by airlines with already-established networks that might be extended into the domestic market — that is, the international carriers - which also have access to inputs at different prices.

\section{Cabotage and other forms of domestic market entry}

The rules of the international regulatory system protect Australian-based airlines from 'import' competition by foreign airlines. There are two types of cabotage, 'consecutive' and 'pure':

- Consecutive cabotage, also known as the 'eighth freedom', refers to the right of foreign-owned airlines to fly a domestic flight stage within the host country as a continuation of an international service; and

- Stand-alone (or pure) cabotage, also known as the 'ninth freedom', refers to the unrestricted right of foreign-owned airlines to provide domestic air services in the host country.

In its final report on international air services (PC, 1998:229), the Productivity Commission recommended that 'Australia should also be prepared to negotiate, on a case by case basis, removal of restrictions on cabotage ...'. The Commission (p. 114) believed that cabotage restrictions granted advantages to Australian airlines:

Restricting access by foreign carriers to the Australian domestic market gives the Australian carriers a solid base from which to extend into international aviation. The same applies to most other countries, with the exception of city economies such as Singapore and Hong Kong. Integrating domestic and international services allows airlines to achieve:

- operational synergies and efficiencies by being able to switch capacity and aircraft between the domestic and international sectors; and

- network advantages such as economies of scope and traffic density as well as the marketing advantages of operating a combined domestic and international network.

In noting the potential benefits of cabotage, the Productivity Commission distinguished the merits of consecutive cabotage from stand-alone cabotage, suggesting that while consecutive cabotage was unlikely to lead to significant gains, stand-alone cabotage was more likely to bring benefits to consumers (PC, 1998:227). Qantas has already indicated that it does not perceive cabotage to be a serious threat to its domestic market position. A Qantas briefing immediately 
following the events of September 11 conceded that cabotage was fairly likely to be introduced in the domestic market. But it argued that this was not an issue in either the short or long term, since other carriers could not offer enough capacity to constitute a viable threat (Qantas, 2001b). The entry of foreign airlines through removal of cabotage restrictions has some potential to stimulate competition, but as a matter of likely outcomes in the current regulatory environment, the Qantas view that cabotage would be unlikely to pose any real threat to domestic carriers in Australia is plausible.

The inability to configure a domestic network optimally is a key factor that is likely to hinder international airlines from competing with existing domestic carriers, particularly when considering the impacts on competition that are likely to flow from only granting consecutive cabotage rights. Optimal network configuration is a function of a number of factors, including flight frequency; number of domestic routes served; aircraft types used; and the impact of the structure of the bilateral agreements already in place. In addition to network configuration issues, international airlines would still face the other barriers to entry noted above, such as establishing brand presence, as well as other sunk costs associated with entry into the domestic market.

An alternative is not to operate on the basis of pure cabotage (with operations managed from an offshore base, using aircraft registered in the home country of the operator), but to set up a new, stand-alone domestic network. Current Australian rules on foreign ownership of domestic carriers do not impede such an approach (as the example of Virgin Blue demonstrates), since the sectoral guidelines of the Foreign Investment Review Board have been amended to permit full foreign ownership of domestic airlines (Anderson 2000) (even though carriers using Australia's international traffic rights cannot be foreign-controlled). Such entrants would escape some of these constraints from the network design perspective, but they would incur greater risks in terms of other barriers to entry - including the responses by incumbents discussed earlier. In addition, they would have to confront the choice between value-based or full service operations. Another key factor in their choice would be the nature of the regulatory environment they face in the domestic market.

\section{Options for Industry Regulation}

It could be argued that there are risks of higher prices and lower service quality in the domestic market associated with the demise of Ansett. It could equally be argued that the competitive constraints imposed by Ansett on Qantas immediately prior to its collapse were limited. Moreover, the rise of Virgin Blue means that competition is now between a VBA and a FSA. Recent history suggests that the state of competition is now stronger and may be far more sustainable than that which existed immediately prior to the collapse of Ansett.

Nonetheless, concern in some quarters over the risks associated with a lack of competition has given rise to debate over the value of, and options for, further industry regulation. While we are limited by the lack of empirical assessments of 
these risks, that discussion is reviewed here. Possible forms of regulation fall into two broad categories: first, imposition of airline-specific regulation; and second, adjustments to section 46 of the Trade Practices Act, which relates to the taking advantage of substantial market power.

\section{Airline-specific regulation}

If Australia were to introduce legislation and guidelines to specifically regulate the behaviour of Qantas, this would not be the first instance of such airline-specific competition regulation. As an example, in Canada, the Competition Act, which regulates anti-competitive behaviour, was amended to constrain Air Canada following its acquisition of Canadian Airlines in December 1999. In addition, guidelines relating to abuse of a dominant position were issued to explain the operation of the amendments to the Competition Act (Competition Bureau 2001a and 2001b). The regulations adopted under these provisions came into force on August 23, 2000. The regulations imposed cover the actions by an incumbent, as quoted earlier in the discussion of barriers to entry. It is possible that the ACCC could seek to impose similar restrictions on Qantas in Australia, although it has already stated that industry-specific regulation should be used only as a last resort.

Telecommunications is the main example of an industry-specific competition regime. This experience was examined by the Productivity Commission (2001b). The Commission observed that industry-specific regulation of this type had the advantage of being able to deal more quickly with anti-competitive conduct. But its disadvantage was the risk of 'regulatory error and overreach' (p. 151) and its deterrence of pro-competitive conduct. These trade-offs are discussed in more detail in the next section.

The Productivity Commission supported the continued use of industryspecific regulation in this case, but noted that it should only be a transitional measure. Its argument for continuation was that the combination of characteristics of telecommunications increased the likelihood of anti-competitive conduct. Of special importance were the number of different segments of the telecommunications market, as well as the rate of technological change and service innovation in those segments. The Commission was concerned that because of these features, there was a risk that market power in some segments could be used to prevent entry into newly developing market segments (p. 172). Network Economics Consulting Group (NECG) provides further commentary on the experience of the application of the special telecommunications sector provisions of the Act (NECG, 2002). While we see significant barriers to entry into the air transport market, we do not see a parallel situation in which such special dangers would require a differential treatment.

We therefore turn now to the possible application of the Trade Practices Act to avoid the sorts of anti-competitive conduct that can arise in air transport markets. 


\section{Strengthening the Trade Practices Act}

A company's conduct can breach the Trade Practices Act (section 46) if the corporation has substantial degree of power in a market and takes advantage of that market power 'for the purpose of eliminating or substantially damaging a competitor ..., preventing the entry of a person ..., or deterring or preventing a person from engaging in competitive conduct ...' (emphasis added). In all cases these purposes refer to the effects on conduct in the market in which the corporation has a substantial degree of power, or in any other market.

These provisions are relevant to the various types of reactions by incumbents in air transport markets noted above. The question is whether the Act is sufficient for the regulator to deal with conduct that is anti-competitive. The ACCC would argue that the answer is no, and it proposes to add to section 46 an 'effects' test so that the text of the section would refer to taking advantage of market power 'for the purpose of, or with the effect or likely effect of, ...' the same purposes listed above (ACCC, 2002:94). It argues (Fels, 2001:17) that

At present the law requires proof of anticompetitive behaviour for a breach of Section 46 to be established. It is the Commission's experience that the difficulties in obtaining sufficient evidence to prove the requisite purpose required by the Trade Practices Act diminish the possibility of successful proceedings, require additional resources and cause delay before both interim and final orders can be sought. An effects test will include conduct with significant detriment to the competitive process where powerful firms take advantage of market power but where proscribed purpose is either absent or unable to be proved.

The ACCC also proposes to amend section 46 to give it 'cease and desist' powers where it suspects a breach has occurred (Fels, 2001:18):

The recipient of the orders could not engage in the conduct specified unless it could prove in court that it did not contravene the Act. This power would be particularly useful in cases involving an allegation of misuse of market power. The problem in the current circumstance is that it takes some time to bring matters to court and the firm breaching the law may actually remove the competition during the time it takes to get to court.

Again, this would not be the first instance where such legislation has been implemented. In Canada, such measures were implemented when Canada Air acquired Canadian Airlines (Competition Bureau, 2002).

There are strong arguments against adding an 'effects' test in the Australian competition regime. These arguments apply to air transport markets as they do to others. One concern is that an effects test will inhibit the use of strategy in the 
competitive process. Competition between firms makes many contributions to economic welfare through its impact on costs, prices, technological progress, product variety and the matching of quality to consumer demand. Even in markets with few sellers firms may compete vigorously with these consequences. At the same time, even strategies used by firms in such markets aimed at getting rid of competitors, or at preventing new ones from being established, may also benefit the customer, at least for a time. It is often difficult to distinguish 'healthy' from 'unhealthy' competition. The main problem with the effects test is that it runs the risk of classifying too many competitive strategies as 'unhealthy'.

It is argued by the ACCC that this problem is not significant. The wording of section 46 includes 'to take advantage of', which on some views demands a higher level test than simply 'to use'. The ACCC asserts that this requirement protects a firm engaged in normal competitive behaviour, and that the language is sufficient once provision for an effects test is added to the existing text of the section (ACCC, 2002:section 3.4).

There are two types of errors in the application of competition policy. One is the risk just referred to - that of incorrectly diagnosing some action as anticompetitive and detrimental to consumer interests when it is not (Type I error). Another is permitting some undesirable behaviour to persist (Type II error). There is a trade-off between these types of risks since a regime that reduces the risk of Type II errors also raises the risk of Type I. A balance is required. Type II errors in general might correct themselves in an open economy with few regulatory or other barriers to entry. The costs of Type I errors are likely to be greater - some of the costs are those associated with inhibitions on firms to compete aggressively. As a result of such inhibitions the benefits of efficient performance, including the associated gains in consumer welfare, would be foregone. In our view, the addition of an effects test to section 46 as an alternative to purpose increases the risk of Type I errors. This is because 'competition' and 'efficiency' are currently regarded as two different concepts in interpreting the TPA provisions (NECG 2002:8-13). Furthermore, as it stands, section 46 lacks the option for a defence on efficiency grounds. In this situation, adding an effects test to that section would loosen the 'filter' against Type I error that is supplied by the purpose test. It would lead to section 46 catching a significant amount of conduct that is desirable from an efficiency perspective and that is consistent with the competitive process. These arguments are presented in more detail in NECG (2002: 40-46) and also by Landrigan, Peters and Soon (2002). Given this assessment of the balancing of the types of errors, we would argue that great caution is required before making the change.

A change in the Act as a result of putting greater weight on reducing Type II errors has another implication. It provides an incentive for entrants to put greater weight than might otherwise be the case on 'the regulatory game' of seeking to have incumbent responses to their entry denounced as anti-competitive. Resources would then be diverted to this process rather than to the application of strategy in the market. Competition for rents not in markets but in regulatory 
forums is far less likely to deliver the sorts of consumer benefits we identified above.

We prefer other approaches for managing the trade-off between these types of risks. These involve the application of a different methodology, which can be characterised as 'purpose plus'. Smith and Round (1998) and Round and Smith (2001) argue for a strategic behavioural approach to the application of a test of competitive conduct. In their framework, 'purpose' is inferred from an analysis of the characteristics of the conduct undertaken in the context of the firm's whole package of strategies. The objective in this approach is to reduce the risk of both types of errors. There may be net benefits from this approach, although the methodology requires further specification and will be more demanding in terms of research effort and the collection of evidence.

\section{Conclusion}

We have explained how recent events have affected competition in Australian domestic air service markets, perhaps increasing the concern in some quarters that Qantas is in a position to take advantage of its market power at the expense of air travellers. Value-based carriers are currently competitors for incumbents like Qantas, but their contribution in all the market segments that Qantas serves remains uncertain. This has led to consideration of whether the current regulatory system has the capacity to correctly assess the conduct that might be observed in a market with these characteristics, whether industry-specific regulation is required, or whether other changes in rules are appropriate. The ACCC's assessment is that industry-specific regulation is a last resort. The major Australian precedent for this type of regulation (the telecommunications specific regime set out in Part XIB of the Trade Practices Act) highlights the great risks such an approach entails, however, and we would not support its application.

That leaves the question of other changes to rules of competition policy. We noted some options - in particular, the addition of an effects test to Section 46 of the Trade Practices Act. Our concern is that this change as currently formulated would increase the risk that conduct is incorrectly diagnosed as anti-competitive, and that conduct that promotes efficiency would be found (or more readily risk being found) unlawful.

There is, however, a further option. An important category of potential entrants is excluded from the market by policy applying to trade in air transport services. We might be more tolerant of suspicious unilateral conduct when regulatory barriers to entry, including by foreign suppliers, are low, and where there is a history of vigorous competition in other markets from which entrants might be attracted. But in the case of air transport there are regulatory impediments to competition from suppliers in the international market. Foreign operators can establish in Australia, but other modes of entry through consecutive cabotage remain restricted. The likelihood of entry via these routes might be small at present, as a consequence of the international regulatory structure. The priority, therefore, is to work on the international regulatory system — rather than 
to create a higher level of domestic regulatory intervention that runs the risk of serious errors in the diagnosis of competitive strategy. Otherwise we face the risk of creating a new regulatory problem while trying to respond to another that already exists.

\section{References}

Amadeus (2001), ‘Amadeus Estimates Immediate Impact from US Tragedy', Amadeus Press Release, Madrid, Spain, 17 September, http://www.global.amadeus.net/en/40/40301 010.jsp?doc_url=/OperaCPs $\backslash$ gwhomepagev1.nsf/id/C1256B0300340092C1256ACA0033F A4C?Opendocument (accessed 2 April, 2002).

Anderson, John (2000), 'International Air Services', a Policy Statement by The Hon John Anderson MP, Deputy Prime Minister and Minister for Transport and Regional Services, June 2000, http://www.dotrs.gov.au/avnapt/ipb/intairservices.htm\#3, (accessed 19 August 2002).

Australian Competition and Consumer Commission (2002), 'Submission to the Trade Practices Act Review', June, http://www.accc.gov.au/fs-pubs.htm (accessed 20 August 2002).

British Airways (2001), ' $£ 110$ million GO sale agreed', June 14, http://www.britishairways.com/press/ (accessed 7 April, 2002).

British Airways (2002a), 'New lower and more flexible UK fares', Press Release, April 3, http://www.britishairways.com/press/ (accessed 7 April, 2002).

British Airways (2002b), 'Future Size and Shape plans unveiled', Press Release, February 13, http://www.britishairways.com/press/ (accessed 7 April, 2002).

Competition Bureau (2001a), 'Enforcement Guidelines on: The Abuse of Dominance Provisions (Sections 78 and 79 of the Competition Act)', July, (available at: http://strategis.ic.gc.ca/SSG/ct02209e.html).

Competition Bureau (2001b), 'Enforcement Guidelines on: The Abuse of Dominance in the Airline Industry', Draft, February, (available at: http://strategis.ic.gc.ca/SSG/ct02118e.html).

Competition Bureau (2002), 'Backgrounder: Amendments to Bill C-23, An Act to Amend the Competition Act and the Competition Tribunal Act', http://strategis.ic.gc.ca/SSG/ct02313e.html (accessed 15 March, 2002).

Fels, A., (2001), 'ACCC Airports and Aviation - Regulatory and Competition Issues', Speech to Airports and Aviation Outlook 2001 Conference, Hilton Sydney (City) Hotel, 12 November.

Landrigan, M, A. Peters and J. Soon (2002), 'An effects test under s. 46 of the Trade Practices Act: Identifying the real effects', Competition and Consumer Law Journal 9(3): 258-88. 
Network Economics Consulting Group (2002), 'Review of Competition Provisions of the Trade Practices Act 1974 (Cth)', July, http://www.necg.com.au/pappub/submission-tpreview-july02.pdf (accessed 19 August 2002).

Productivity Commission (1998), International Air Services, Report No. 2, AusInfo: Canberra.

Productivity Commission (2001a), Price Regulation of Airport Services: Draft Report, Melbourne, August.

Productivity Commission (2001b), Telecommunications Competition Regulation, Report No. 16, AusInfo, Canberra.

Qantas (2001a), 'Preliminary Monthly Traffic \& Capacity Statistics', September, http://investor.qantas.com.au/traffic/details.cfm?ID=66 (accessed 2 April, 2002).

Qantas (2001b), 'Investor and Analyst Briefing', 18 September.

Qantas (2002), '2001/02 Interim Results Presentation', 21 February'

Round, David and Rhonda Smith (2001), 'Strategic Behaviour and Taking Advantage of Market Power: How to Decide if the Competitive Process is Really Damaged', mimeo, Adelaide University.

Smith, Rhonda and David Round (1998), 'A Strategic Behaviour Approach to Evaluating Competitive Conduct', Agenda, 5(1):25-36.

USA Today (2001) 'Ryanair Flies High While Rivals Struggle', by Elliot Blair Smith, 4 October, http://www.usatoday.com/money/biztravel/2001-10-04-ryanair.htm (accessed 7 April, 2002).

The first draft of this material was presented at an APSEM seminar on April 5, 2002. The authors thank participants and also a referee for comments. Special thanks are due to the editors for their interest in the paper. The authors remain responsible for any errors here. Findlay's contribution is supported by a grant from the Australian Research Council. Support from by the Groupe d'Economie Mondiale de Sciences Po (GEM) in Paris is also acknowledged. 